\section{Implementation of Basel II and Profitability of Banks in Pakistan}

\author{
Muhammad Ramzan Sajid ${ }^{1}$ Hassan Mujtaba Nawaz Saleem ${ }^{2}$
}

The Journal of Educational Paradigms 2019, Vol. 01(01) 24-34

(C) Authors

ISSN (Print): 2709-202X

ISSN (Online): 2709-2038

DOI: $10.47609 / 0101042019$

\begin{abstract}
This study examines the impact of credit risk and liquidity risk on the profitability of the banks in Pakistan before and after the implementation of the Basel II policy in Pakistani Banks. For this purpose, five private commercial banks of Pakistan selected as the sample of our study. The balanced panel data of these banks for ten years (2006-2015) is used to analyze the model. The data is collected from the annual reports of the selected banks. The impact of pre and post-Basel-II policy implementation is also measured using four years (2006-2009) as pre-Basel-II and six years (2010-2015) as post-Basel-II to compare the impact of Basel-II implementation in the banks. The regression model estimation technique is used, which is selected based on the unit root test. The fixed effect and random effect models are used based on the Hausman test to estimate profitability determinants. The models are applied in three phases as the whole period, pre-Basel-II, and post-Basel-II implementation period. Further studies could be developed by adding more variables to the regression model to check their impact on bank profitability. The sample size can be increased to all commercial banks, and further, this study can also be discussed in Islamic banking and microfinance institutions. Further, the dependent variables could also be increased to enhance the results of bank profitability. The number of observations could be improved to describe the risk management more prudent than this. The study suggests that banks have to follow strategies that provide adequate diversification in credit risk and liquidity risk management to mitigate these risks and enhance the profitability. It is further recommended that adopting a sound risk management system and strong corporate governance will reduce the credit risk and liquidity risk and ultimately improve the profitability of banks in Pakistan.
\end{abstract}

Keywords: Profitability, Credit Risk, Liquidity Risk, Basel-II, Banking Sector of Pakistan.

As the business sector is becoming more complicated due to globalization, communication, information technology, competition, and modernization of delivering the goods and services in the market, the intangible assets and intellectual capacity are required to be increased. Still, these factors are encountered by many hazards and organizational risks (Masoud et al., 2013). The major banks and other financial institutions face different types of risk to its product market and capital market. Similarly, the banking sector's financial structure is also facing many risks day by day due to the continuous changes in the economic system and environmental factors (Masoud et al., 2013). In recent times, the banking sector is providing financial services through its intermediation role to the community for economic stability and development of any nation (Kaaya \& Pastory, 2013). The financial stability of any country is measured by the banking industry's performance and how it provides its services efficiently and effectively to the customers (Funso et al., 2012). The stability and growth of the economy are based on the process of financial intermediation because it is an essential requirement (Halling \& Hading, 2006). The banking system plays efficiently and effectively in the economy (Diamond \& Rajan, 2001). It explored that to ensure survival and profitability as the primary concern of the banks, the valuable economic activities have to be arranged by the management.
(Abbas et al., 2012) discussed the Banking system in Pakistan as, it carried out under the Banking Companies Ordinance, 1962. State bank of Pakistan is the central bank that plays its role in managing and control the function of the banking sector in Pakistan. The commercial banks' issues are resolved by the state bank of Pakistan, which develops the regulation for the banks to mitigate the miss-management in the banking system. The monetary and fiscal policies are developed and regulated by the State bank to control inflation and other risks in the country. There are twentyone scheduled commercial banks in Pakistan that perform in the country very well and contribute its share in the development of the Pakistani economy. According to (Abbas et al., 2012), the commercial banks play their role in tackling and manage the economic difficulties of the businessmen, to achieve and promote their business matters with the help of financial resources from this banking system.

(Abdullah et al., 2012) discussed that the banking sector plays a vital role in developing the economic and financial position of any country because the banking sector contributes a fundamental part of the economic development of any state. There are 6 Islamic banks, nine investment banks, six foreign banks, and 21 commercial banks operating in the country in the stiff competitive environment of the economy. The banking sector's performance is increasing day by day, attracting most foreign banks to start their business activities in Pakistan.

\footnotetext{
${ }^{1}$ Department of Management Sciences, The Islamia University of Bahawalpur, Pakistan. Corresponding author: ramzansajid05@ gmail.com

${ }^{2}$ Othman Yeop Abdullah Graduate School of Business - UUM, Malaysia
} 
During the last thirty years, the banking sector has faced a remarkable number of banking and the financial crises worldwide. (Haneef et al., 2012) said that the banking sector is providing banking services and consultancy to its customers and business entities for many years. Due to constant innovation and competition, a more comprehensive array of banking products and services for the customers are entered among the banking sector. According to (Hosna et al., 2009), the banking sector is facing a very turbulent situation globally, so; There is a need for close examination of various issues to identify the main reason for the problem related to the banking sector. For the primary disturbances in the international monetary system and financial crises in the banking market. The Basel Committee on Banking Supervision (BCBS) is established by the Governors of the central bank of the Group of ten countries in the end period of 1974 for banking regulatory system to carried out some significant reforms to cover up these issues in the banking industry (Hussain \& Ahmad, 2012). These reforms include the Basel Accord, Basel- I, and Basel- II, which are issued by BCBS (Hosna et al., 2009).

This research is conducted to evaluate the important aspects of Basel II, and to understand the implementation of Basel-II on the profitability of the banking system. Also, to explain the effect of credit risk and liquidity risk on the profitability of the banks. An efficient risk management system is required to be implemented as managing the risk is the main task when observed and identified (Rim et al., 2001). Controlling and managing the risk is better before its occurrence, and sound risk management is to identify and resolve the risk in time. Financial sector risk management is more critical from other economies (Shafiq \& Nasr, 2010). AlTamimi and Al-Mazrooei (2007) argued that the main objective of an organization is to maximize the profit and offer maximum value to shareholders. Hence, the effective risk management system is critical to achieving the profitability goals.

So there is a need for proper regulations to mitigate these risks. For this purpose, Basel, was introduced. Still, it was unable to cover the risks fully, so after the financial crises of 2007-08, there is a need to change and improve the Basel I. Basel Committee introduced Basel II in 2008 with a variety of techniques to measure the risks. Basel II is more flexible in changing the environment and can successfully implement in the banking system. Thus the Basel II has to be adequately implemented to teach the important lessons that can support the banking system to respond to the financial, operational, and market risk and improve the overall risk management in the future. So in these circumstances due to inadequate risk management system and non-compliance of Basel II practices properly, the banking sector cannot survive in the market (Haneef et al., 2012).

This area is a critical need to be discussed to evaluate the important aspects of Basel II and the implementation of Basel-II on the profitability of the banking system. Also, to explain the effect of credit risk and liquidity risk factors on the profitability of the banks. Therefore this phenomenon of interest is selected for the study. Currently, in the banking sector of Pakistan, Basel-II is in the adoption phase. Thus this study will help in the proper implementation of Basel-II by identifying the problems associated with the application of Basel-II. This study will also provide the mechanism to reduce the risk by increasing the risk controls and results in increasing the profitability in the banking sector. Following will be the research objectives to be discussed,

- To identify the impact of risk factors on the profitability of banks.

- To examine the impact of risk factors on the profitability of banks in Pre Basel-II policy implementation.

- To investigate the impact of risk factors on the profitability of banks in Post Basel-II policy implementation.

- To compare the impact of risk factors on the profitability of banks in Pre \& Post Basel-II policy implementation.

\section{Literature Review}

Rahman, (2012) observed the banking system's significance, the banking sector reforms are the most focusing reforms all over the world, which improved and sounded the business sector for efficient and effective intermediation of financial systems. According to Schumpeter (1934), an efficient and effective banking system consists of an effective and functional financial system that makes the bases of an efficient financial system of Banks, as this is the underlying source of finance for investment in the long-term securities becomes the primary sources of economic growth. Banks tend to improve the country's economic stability to contribute to economic growth by providing the banking services. The degree to which a bank stretches out credit to the general population for gainful exercises quickens the pace of a country's economic development and long haul maintainability (Funso et al., 2012). Conceived of the way of intermediation, banks confront four essential Risks: credit Risks, market/ liquidity Risks, operational Risks, and the interest rate Risks. A large portion of these Risks is of a customary sort: credit Risk, investment rate Risk, liquidity Risk. Nonetheless, various Risks are later, for example, administrative Risk, coin Risk, and human assets Risk. The recent decades have seen emotional misfortunes worldwide and nearby, keeping the money industry (Haneef et al., 2012). In every economy, the risk management plays a crucial role. (Eken \& Kale, 2013) defined the risk as when the uncertain outcome has occurred, it is called the risk. In any environment where various business organizations are working, the uncertainty exists, so it is concluded that risk is faced by every type of risk (Shafiq \& Nasr, 2010). Business growth is impossible without risk in the business economy (Asim et al., 2012). Thus, the Banks based on business activities also face different risks like other businesses in the marketplace. The banks facing these risks have required an efficient and effective tool to manage their risk. The bank has the task of exploring and managing the risks in the banking sector (Fatemi \& Fooladi, 2006). This Basel Accord is used to protect the banking system worldwide as an attempt to control the impact of financial crises by developing the systematic risk management procedures (Makwiramiti, 2008). Every organization needs efficient and effective risk management policies. This is also a vital responsibility of every bank in the country, as to boost the organizational performance risk management plays an active role. In the long run, many banks faced excessive risk due to the uncovered shortcomings of financial crises the economy faced in the past, which has affected the performance of the organization due to these risk management practices (Sitanta, 2011). Banks can grab more significant opportunities to enhance their performance 
by following risk management practices properly. (Koch and MacDonald, 2009) explained that there are six types of banking risks: credit risks, liquidity risks, market risk, operational risks, reputation risk, and the legal risk. These risks assert a negative impact on the financial organization's performance and affect the market value, shareholder's equity, bank liabilities, and profitability. (Zheng \& Shen, 2008) defined the liquidity risk as to the outcome, which arises from the different amounts of the assets and liabilities sides of the balance sheet. The study also stated that to provide a better risk measurement approach, liquidity adjusted conditional value at risk $(\mathrm{VaR})$ is used to measure the more realistic loss which arises in the presence of the liquidity risk.

\section{Credit Risk}

Boffey and Robson, (2007) explained that the credit risk usually had been defined as the risk that has the most significant impact on the bank's performance. Credit risk is the risk that becomes a default as a result of a loan transaction by the counterparties, that's mean that the borrower has failed to pay back the interest and principal amount on time (Koch \& MacDonald, 2000). The credit default plays an important, influential variable for the bank's credit risk while considering this risk as credit risk. According to Gestel \& Baesens (2008), credit default may be incurred due to many reasons. Usually, the situation of financial stress is faced by the obligator, which may cause a bankruptcy condition. On the other hand, legal matters or fraud may also lead to refuse the compliance of the debt services obligation by the borrower.

Credit risk is also defined as a risk of loss due to the credit derivative market. It can cause a downgrading in credit rating, known as credit migration (Choudhry, 2011). (Abdullah et al., 2012) discussed the credit risk in domestic and foreign banks working in Pakistan. He showed that the Linear Regression Model was used for analysis by using OLS techniques and found that credit risk has significant and positive relationships in domestic banks while positive and insignificant with foreign banks working in Pakistan. (Kaaya \& Pastory, 2013) explored that the firm performance was affected by credit risk. He showed that above both variables have negative co-efficient due to which the profit is also decreased.

Ahmed et al., (2011) discussed the Islamic Banking system in Pakistan for the period 2006-09 using 6 Islamic banks as a sample. The data was collected through secondary sources. The relationship was checked by using Pearson correlation techniques linear regression was also used. The results depicted that the gearing and NPL ratios have a direct link with credit risk. (Sufian, 2009) discussed the determinants which affect the domestic and foreign Malaysian banks' profitability during the 2000-04 periods. The results showed that in Malaysian Bank's higher credit risk produced lower profitability. (Aduda \& Gitonga, 2011) discussed the relationship of credit risk and profitability by using generalized least square (GLS) method for analysis of linear regression. The results showed that $75 \%$ of respondents accepted that there was a relationship between credit risk and profitability.

Finally, NPLRs and CAR ratios have been chosen based on the literature and frequently application by various researchers. The NPLRs are related to the bank's loan, and bad debt loans are closely associated with banks' credit risk. This ultimately influences the efficiency of credit risk management. Capital adequacy (CAR) ratio helps to estimate the capital amount of banks concerned with the credit risk exposure of the risk-weighted assets. Thus, it is also an important indicator for banks to consider it for credit risk management.

\section{Liquidity Risk}

According to (Bonfim \& Kim, 2012), there arises a risk due to complexity in the function of banks, which is deeply rooted in their core function; their unique intermediation role. While granting loans to customers \& entrepreneurs, banks use their limited amount of resources to provide them the opportunity to finance their consumption demands and investment. (Dinger, 2009) suggested that the emerging markets' liquidity risk has been minimized due to trans-national banks because, in normal conditions, low liquid assets are held. In crises, the liquid assets have been held by the banks. (Vaihekoskia, 2009) stated that the stokes with high returns during systematic risk have a negative relationship with the price of liquidity risk. So, this liquidity risk is treated as a market-wide risk compared to asset-specific risk because it is sufficient for all the risk related to liquidity. (Uddin, 2009) determined the negative relationship between the liquidity risk and the stock returns when the stock becomes more Ill-liquid, the risk increase as compared to the rate of return, which showed that stock liquidity fluctuations did not affect the return of the stock.

Shen et al., (2009) discussed the model of liquidity risk and the bank performance by using instrumental regression on the panel data and applied the two stages least squares (2-SLS) technique to estimate the relationship. The study employed an alternative liquidity risk variable besides liquidity ratio, the financing gap ratio (FGAPR), and evaluated the liquidity risk model's reasons for an unbalanced panel set of data for the twelve commercial banks from 1994 to 2006 . They found that the liquidity risk is a central part of the bank performance, including size, liquid assets risky and less risky components, and checking the dependence on the external sourcing, supervisory and regulatory determinants, and the macroeconomic indicators.

In the study (Vodova, 2011), the liquidity of commercial banks' determinants in Slovakia was considered. The results showed that the liquidity of banks was dropped due to the financial crises in the market. Bank's liquidity was negatively associated with the profitability. However, (Saunders \& Cornett, 2006) proposed that the financing gap ratio should be adopted by deviating the standard practices to measure liquidity risk. The banks used it as an excellent alternate to measure the liquidity risk exposure to minimize the failure chances (Shen et al., 2009). Hence in our study, the financial gap (FGAPR) ratio and the net loan to deposit (NLD) ratio are used as reasonable proxies of liquidity risk. The details of these indicators will be discussed in the following section.

\section{Profitability}

Bank profitability in the thorough literature reviewed has been the return on asset (ROA) and the return on equity (ROE) in this study (Sufian \& Chong, 2008). (Aduda \& Gitonga, 2011) suggested that to measure the profitability, there are different ratios which are used by the banks. Some of them are the ratio of return on income; 
cash return on asset and return on equity (ROE) ratio. Return on income is the preferred ratio over return on investment in the bank. (Frazer \& Zhang, 2009) Investigate that Return on Equity (ROE) may be considered the primary measurement of profitability in the banking sector.

\section{Basel}

Balin, (2008) explained that the Basel Committee is probably the most compelling and misjudged assertion in current worldwide Finance. Drafted in 1988 and 2004, Basel I and II have introduced another time of worldwide keeping money participation. Form the background of Bank of Herstatt disaster, "G-10 nations and Luxembourg framed a standing panel under the sponsorship of the Bank for International Settlements (BIS) called the Basel Committee on Banking Supervision (BCBS)". The details about Basel-I and Basel-II are discussed under the following headings.

\section{Basel I}

The Basel committee took the initiative in the 1980s to develop a standard of risk-based capital adequacy. The Basel accord consists of regulatory capital, risk exposure measures, and specified rules for maintaining the capital about risk (Hasan, 2002). This accord develops the standard for addressing credit risk by requiring to maintain the minimum capital standard i.e., banks of different countries started measuring the 8 percent of assets according to the risk associated with them.

There should be proportionate between the capital of the bank, and the associated risk, the main theme behind this was pure (Stevens, 2000). The Basel committee sets out a single standard for international banks due to two reasons. Firstly, the committee was of the view that this framework would enhance banks' capital position by providing the stability and soundness to the system of international banking. Secondly, a global approach for the banking system would reduce the complexity and inequalities in different countries. In 1988 this Basel accord was given the name of Basel I, and it successfully achieves the two targets. The first one was the bank's stability by requiring a sufficient level of capital to be maintained by internationally active banks. Secondly, it provides the uniformity to the international banking system (Alexander, 2003).

\section{Basel II}

There are a variety of financial instruments that are used to improve the ability of banks in trading activities like the credit derivatives. From a global perspective, high operational activities are achieved through a more extensive and sophisticated banking system rapid development (Lind, 2005). Hence, a capital requirement needs through the framework with necessary revisions. This framework to maintain the bank capital was started in 2004 and implemented in 2007 by applying internationally active banking systems. This Basel-II is based on the three pillars; Pillar I explains the minimum capital requirement, which is calculated as its regulatory capital rule. The required minimum capital requirement is $8 \%$, which is unchanged by the Basel II, but the calculation method of this capital by risk-weighted assets has been revised (Ferguson, 2003; Lind, 2005). The Pillar II consists of the supervisory review in the process of the minimum capital requirement in the banks. Therefore, in the case of the capital adequacy planning and assessment, the supervisory review requires proper interaction among the supervisor and the banks (Lind, 2005). In the end, the Pillar III, stronger market discipline is necessary to accomplish the banking activities by identifying important capital adequacy procedures and risk assessments (Ferguson, 2003). Thus, these pillars play their role in enabling the market participants to some extent to assess the target capitalization and risk profile of the bank. (Rowe et al., 2004) To improve the essential risk management procedure, banks have to use its Basel II leverage to allow banks by addressing the issue of data properly instead of putting money for just the regulatory compliance.

Based on the literature discussion about Basel-II and its implementation in developing nations. The Pakistani banking system is also going to implement the Basel-II in its banking system to meet the necessary banking regulation to avoid the risks. Pakistan is also an under-developed country and needs to improve the banking system further. Thus, the current study is designed to check Basel-II's implementation and its impact before and after the introduction of Basel-II policies. Credit risk and liquidity risk have chosen two proxies for each variable, and profitability also includes two indicators. Credit risk consists of the non-performing loan (NPLR) and capital adequacy (CAR) as the proxies. Simultaneously, the financing gap ratio (FGAPR) and net investment to deposit (NLD) represent the liquidity risk indicators. And the profitability of banks includes the ROA and ROE as its proxies.

In conclusion, we will check the relationship between the credit risk and liquidity risk with the banks' profitability and measure the impact of Basel-II in pre- and post-Basel-II policy implementation. The above six indicators (ROA, ROE, NPLR, CAR, FGAP, and NLD) are chosen as the study's foundation, which frames the research model. The ratios representing the credit risk, liquidity risk, and profitability will be used in our research as the main body of our research model. The model will be tested by applying the appropriate estimation techniques to explore the results for discussion and conclusion.

Theoretical Framework

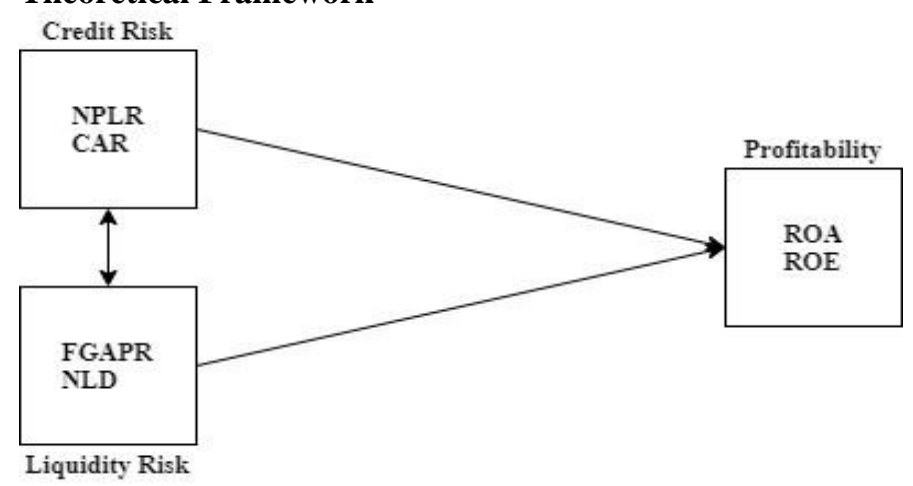

Figure 1: Policy framework

\section{Research Methodology}

At, present, 21 commercial banks are operating in Pakistan as the theme of the study is to measure the quantitative impact of credit risk and liquidity risk on the profitability of banks in Pakistan for ten years from 2006-2015. So, five private commercial banks have been chosen from the 21 existing commercial banks. These banks 
are named as Habib Bank Ltd. (HBL), United bank Ltd. (UBL), The MCB Bank Ltd. (MCB), Allied bank Ltd. (ABL) and Bank Alfalah Ltd. (BAF) and selected as the sample for the study. These are selected as top banks mentioned by total assets (Banking Survey by KPMG, 2015). The data consists of a time series and cross-sectional data set. So, the data is pooled into a panel and analyzing by using Panel Data regression techniques. The selection of the sample is justified on the following points;

- The five banks were rated as the top five private commercial banks in Pakistan by the KPMG banking survey of Pakistan in 2015 (Snapshot of results of Banks in Pakistan) and from the commercial databases.

- These banks relatively account for more than $50 \%$ of the total assets of the entire banking industry. These contain $51.53 \%$ of the total assets of the commercial banks of Pakistan.

- The five selected banks have also accounted for over $50 \%$ of the total equity and shareholders in the commercial banking. As the proportion of these banks has $54.10 \%$ of the total capital and 50.20 shareholders share only these five banks.

- The banks have relatively large customers in the market and also active members of the Karachi stock exchange.

- These banks also contribute $60 \%$ of the taxation among all the commercial banks across Pakistan.

\section{Data and Sources of Data}

In previous research, various researchers used 5 to 10-year annual reports to collect data so that researchers followed that pattern (Akhtar \& Ali, 2011; Elsiefy, 2013; Hosn et al., 2009; Kaaya \& Pastory, 2013). For our study, the source of data is Annual Reports of selected banks for ten years, 2006-2015. This study is mainly looking into credit risk and liquidity risk management and their impact on the profitability of banks. For this purpose, the details annual reports, disclosure, financial statements, and notes to financial statements within the sample banks' annual reports are used to collect the data for our research.

\section{Econometric Model Specification}

This part will consist of the econometric models' choice and specification for our study. The panel data regression technique will be used to estimate the Credit risk and the liquidity risk and its impact on the banks' profitability. Baltagi (2001), cited by Gujarati(2004), explained that time series and cross-sections data are used in panel form, resulting in more informative, variability, and less collinear among all the variables. It also gives more $\mathrm{df}$ and efficiency. To check the relation between Credit risk, liquidity risk, and profitability of banks, we will use the linear regression model by the following equation.

$Y_{j t}=\delta_{j}+\alpha^{\prime} X_{j t}+\epsilon_{j t}$,

Where $\mathrm{j}$ is an indicator representing an individual organization as bank variables, $\mathrm{T}$ represents as a year. Yjt refers to the dependent variables as ROA and ROE, and it is the observation of the organization $\mathrm{j}$ in a specific period $\mathrm{i}$-e year. $\mathrm{Xi}$ represents the independent variables of the organization; Ejt represents the normally distributed random variable error term.

The structural equations are modified based on econometric specification, which is followed by Shen et al. (2009) after thoroughly literature review (Aspachs et al., 2005; Sufian \&
Chong, 2008; Vodova, 2011). Following are the two model specification equation for our study depends upon our two dependent variables of profitability like ROA and ROE.

$R O A_{j t}=\delta_{j}+\alpha^{\prime} N P L R_{j t}+\alpha^{\prime} C A R_{j t}+\alpha^{\prime} F G A P R_{j t}+\alpha^{\prime} N L D_{j t}+\epsilon_{j t}$,

$R O E_{j t}=\delta_{j}+\alpha^{\prime} N P L R_{j t}+\alpha^{\prime} C A R_{j t}+\alpha^{\prime} F G A P R_{j t}+\alpha^{\prime} N L D_{j t}+\epsilon_{j t}$,

Where;

$R O A_{j t}=$ Return on asset for $\mathrm{j}^{\text {th }}$ bank in $\mathrm{t}$ time period.

$R O E_{j t}=$ Return on equity for $\mathrm{j}^{\text {th }}$ bank in $\mathrm{t}$ time period.

$\delta_{j}=$ Constant

$\alpha^{\prime}=$ Slope of coefficient.

$\epsilon_{j t}=$ Error term

The above equations are used to check the bank profitability by using the fixed effect and random effect model. The Hausman test will be applied to choose between the fixed effects (FE) as an appropriate or random effect (RE) to determine whether the coefficients can be estimated to describe the results.

\section{Data Analysis Technique}

this purpose, panel data is used from 2006 to 2015 and the data collected from the bank's annual reports. The research will be conducted in three phases to explore our research objectives. The first part of our study will show the effect of credit risk and liquidity risk factors on the bank's profitability for the whole period of ten years (2006-2015). In the second part, the period of 4 years (2006-2009) was selected to check the results in PreBasel-II policy implementation considering Basel-II's transition period in the analysis. In the end part, the period of six years (2010-2015) was used to estimates the results in the Post BaselII policy implementation. This period is selected based on a roadmap designed for the implementation of Basel II in Pakistan (Malik, 2008; Pakistan, 2005 \& Zaidi, 2006). Different data analysis techniques are applied to this data for the selection of an appropriate model.

The estimation of panel data can be done by applying a fixed effect (FE) or the random effect model (RE), also known as the error of the component model. The fixed effect model is used as a statistical tool to explain the observations as explanatory variables and treated as non-random quantities. (Baltagi, 2001) said that the Hausman test would be employed to choose between the fixed effect and random effect model. The (Hausman, 1978) discussed that the estimates are significant or not from the fixed effect or the random effect. In simple, the Hausman test gives the null hypothesis as the preferred model will be a random effect model. In contrast, the alternative hypothesis is given as the preferred model will be a fixed-effect model.

\section{Results and Discussion \\ Descriptive Analysis}

In this above table, the descriptive analysis is conducted. The data consists of 10 years of panel data of five private commercial banks of Pakistan from the period 2006-15. The descriptive statistics explained that the average NPLR is 8.34, among the standard deviation of 2.57. The average of CAR is 14.60, and the standard deviation is 4.07 , the average value of NLD is 58.59 , and the standard deviation is 12.84 . The average value of FGAPR is (31.99) having the standard deviation 10.11, ROA having the average value of 1.97 with standard deviation 0.90 , the average 
value of ROE is 24.23 with standard deviation 7. The Maximum Value of NPLR, CAR, NLD, FGAPR, ROA, and ROE are 14.00, 22.25, 79.39 (15.34), 4.06, and 45.00, respectively. The minimum Value of NPLR, CAR, NLD, FGAPR, ROA, and ROE are 4.14, 1.90, 38.74, (49.84), 0.25, and 4.83, respectively.

Table 1: Descriptive Statistics

\begin{tabular}{lcccc}
\hline Variables & MEAN & MIN & MAX & STD \\
\hline ROA & 1.97 & 0.25 & 4.06 & 0.90 \\
ROE & 24.23 & 4.83 & 45.00 & 7.50 \\
NPLR & 8.34 & 4.14 & 14.00 & 2.57 \\
CAR & 14.60 & 1.90 & 22.25 & 4.07 \\
NLD & 58.59 & 38.74 & 79.39 & 12.84 \\
FGAPR & $(31.99)$ & $(49.84)$ & $(15.34)$ & 10.11 \\
\hline
\end{tabular}

Correlation Analysis

Correlation analysis is one of the most used statistical tools to measure the relationship between two variables in scientific research. Table 2 shows the following results regarding NonPerforming Loan, Capital adequacy, financial gap ratio, net loan to deposit, ROA and ROE;

The test shows that ROE is significantly correlated with ROA in the banking sector; Non-performing loans are highly associated with ROA but negatively correlated to ROE. Capital adequacy ratio is highly correlated with ROA, ROE, and non-performing loans. Financial gap ratios are correlated with ROA and ROE but negatively associated with non-performing loans and capital adequacy ratios. Net loan to deposit ratios are linked with ROA, ROE, and highly correlated with financial gap ratios, but these are negatively associated with non-performing loans and capital adequacy ratios. The matrix showing that the multi-collinearity problems are not severe, as Kennedy (2008) suggested, multicollinearity is a problem when the correlation is over .80 , which does not exist in the above matrix.

Table 2: Correlation Analysis

\begin{tabular}{lllllll}
\hline Variables & ROA & ROE & NPLR & CAR & FGAPR & NLD \\
\hline ROA & 1.000 & & & & & \\
ROE & 0.770 & 1.000 & & & & \\
NPLR & 0.148 & -0.137 & 1.000 & & & \\
CAR & 0.661 & 0.311 & 0.218 & 1.000 & & \\
FGAPR & 0.129 & 0.307 & -0.370 & -0.355 & 1.000 & \\
NLD & 0.022 & 0.253 & -0.452 & -0.468 & 0.968 & 1.000 \\
\hline
\end{tabular}

Correlated Random Effects - Hausman Test

The results are based on the association of credit risk and liquidity risk with the baking sector's profitability. The model performs reasonably well, with most of the variables remaining stable among the various regression models.

Table 3: Test Summary

\begin{tabular}{lllllll}
\hline & \multicolumn{2}{c}{ Dependent Variable (ROA) } & \multicolumn{3}{c}{ Dependent Variable (ROE) } \\
\hline Test Summary & $\begin{array}{l}\text { Chi-Sq. } \\
\text { Statistic }\end{array}$ & $\begin{array}{c}\text { Chi- } \\
\text { Sq. } \\
\text { d.f. }\end{array}$ & Prob. & $\begin{array}{c}\text { Chi-Sq. } \\
\text { Statistic }\end{array}$ & $\begin{array}{c}\text { Chi- } \\
\text { Sq. } \\
\text { d.f. }\end{array}$ & Prob. \\
\hline Period random & 9.752932 & 4 & 0.0448 & 5.468387 & 4 & 0.2425 \\
\hline
\end{tabular}

\section{Results of Profitability Model for the Period 2006-2015}

The results in table 4 show that NPLR has positively and significantly influenced the profitability indicator ROA as the probability value of NPLR is 0.0174 , which shows that profitability is positively affected by NPLR. While capital adequacy (CAR) has a statistically significant and positive impact on ROA, the p-value of CAR is 0.0000 , which shows that CAR is aggressively influencing the banks' profitability (ROA). This gives support to the researches of earlier studies on the relating to findings and impact of NPLR and CAR on the profitability of banks ((Ali et al., 2011; Elsiefy, 2013). The financial gap (FGAPR) ratio insignificantly affects the profitability of banks, showing that it has not played a role in determining bank profitability. While the net loan to deposit (NLD) ratio is also a statistically insignificant relationship with ROA showing the probability of 0.4015 .

The intercept value of the coefficient is also significant. It shows that $100 \%$ increase in CAR will increase the profitability (ROA) by $21 \%$ and $100 \%$ increase in NLD will enhance the profitability by $37.27 \%$ which is suitable for the banking sector and satisfy the results given by the previous researches (Akhtar et al., 2011; Ali et al., 2011; Siaw, 2013). R squared and adjusted $\mathrm{R}$ square is considered very high and significant $(73.7 \%$ and $64.20 \%$ respectively), which explained that $73.7 \%$ of total variations in ROA are defined by the joint variation of all the independent variables. The F static showing the value of 7.76 is not significant, concluding the regression results are valid. It means that it is similar across all the banks of Pakistan. The estimated Durbin Watson stat is relatively high, suggesting no auto-correlation in the data set.

The above table shows that the only CAR is statistically significant, and all other variables have an insignificant relationship with the profitability (ROE). The slope coefficient shows that only FGAPR has a negative sign, which means that an increase in the financial gap of $100 \%$ causes a $10.8 \%$ decrease in the profitability (ROE). While a $100 \%$ increase in net loan to deposit ratio will increase the profitability by $70 \%$. The $\mathrm{R}$ square is relatively high, with almost $65 \%$, showing that $65 \%$ of profitability is generated using these independent variables. The $\mathrm{F}$ static value of 5.13 indicates that this is insignificant and explained the results of the regression to be valid. It means that it is similar across all the banks of Pakistan. Durbin Watson statistics is also $96 \%$, which is relatively high and depicted no autocorrelation in the data.

Table 4: Fixed and random effect model (Model-1)

\begin{tabular}{|c|c|c|c|c|c|c|c|c|}
\hline \multirow[b]{2}{*}{ Var } & \multicolumn{4}{|c|}{ Dependent Variable (ROA) } & \multicolumn{4}{|c|}{ Dependent Variable (ROE) } \\
\hline & Coeff. & S.E & $\mathbf{T}$ & Prob. & Coeff & S.E & $\mathbf{t}$ & Prob. \\
\hline $\mathrm{C}$ & -3.92 & 4.34 & -0.90 & 0.37 & -39.4 & 41.8 & -0.94 & 0.35 \\
\hline NPLR & 0.11 & 0.04 & 2.49 & 0.01 & 0.46 & 0.42 & 1.07 & 0.28 \\
\hline CAR & 0.21 & 0.03 & 7.83 & 0.00 & 1.05 & 0.25 & 4.16 & 0.00 \\
\hline FGAPR & 0.00 & 0.04 & 0.15 & 0.87 & -0.10 & 0.42 & -0.25 & 0.80 \\
\hline NLD & 0.03 & 0.04 & 0.84 & 0.40 & 0.70 & 0.42 & 1.65 & 0.10 \\
\hline \multicolumn{5}{|c|}{$\begin{array}{l}\text { Effects Specification } \\
\text { Period fixed (dummy variables) }\end{array}$} & \multicolumn{4}{|c|}{$\begin{array}{l}\text { Effects Specification } \\
\text { Period fixed (dummy variables) }\end{array}$} \\
\hline \multicolumn{3}{|c|}{ R-squared } & \multicolumn{2}{|l|}{0.737} & \multicolumn{2}{|c|}{ R-squared } & \multicolumn{2}{|l|}{0.649} \\
\hline \multicolumn{2}{|c|}{ Adjusted R-squared } & & \multicolumn{2}{|l|}{0.642} & \multicolumn{2}{|c|}{$\begin{array}{l}\text { Adjusted R- } \\
\text { squared }\end{array}$} & \multicolumn{2}{|l|}{0.523} \\
\hline \multicolumn{2}{|c|}{ F-statistic } & & \multicolumn{2}{|l|}{7.761} & \multicolumn{2}{|c|}{ F-statistic } & \multicolumn{2}{|l|}{5.133} \\
\hline \multicolumn{2}{|c|}{ Durbin-Watson stat } & & \multicolumn{2}{|l|}{0.911} & \multicolumn{2}{|c|}{ Durbin-Watson } & \multicolumn{2}{|l|}{0.960} \\
\hline
\end{tabular}

Results of Profitability Model for the Period 2006-2009 (Pre Basel-II Implementation)

In table 5, the analysis has been done for four years (2006-2009). The purpose of this analysis is to check the impact of these independent variables in pre-Basel-II policy implementation on banks' profitability. The examination of the results in the above table for profitability (ROA) shows that capital adequacy and financial gap ratio (FGAPR) have a positive and statistically significant relationship with the bank profitability. The nonperforming loans (NPLR) have an insignificant relationship with bank profitability (ROA) with the negative sign of slope coefficient, which shows that higher the non-performing loans 
lower will be the profitability. This gives support to the earlier studies (Kaaya \& Pastory, 2013), which explained that an increase in the credit risk tends to lower the firm performance, as this shows the negative coefficient, which tends to reduce the profitability. So the $100 \%$ increase in NPLR will decrease the profitability by $12.71 \%$.

Capital adequacy (CAR) has a statistically significant and positive relationship with the profitability of banks (ROA) as the p-value is less than $5 \%$, and it has a positive coefficient, which means that $100 \%$ increase in CAR will cause $13.30 \%$ increase in the profitability (ROA). This result supports the findings of previous researches (Akhtar et al., 2011). The financial gap ratio (FGAPR) also has a positive and significant relation with profitability (ROA) at the significance level of less than 5\%. The coefficient of FGAPR is relatively high, which shows that an increase in the financial gap tends to increase the bank profitability. On the other hand, the net loan to deposit ratio (NLD) has an insignificant relationship as the p-value is above $5 \%$. Still, the coefficient has a negative sign, which explains that a $100 \%$ increase in NLD will decrease the profitability by $50.71 \%$.

R squared and adjusted R squared have relatively high 94.24 \& $90 \%$ respectively and significant, which explain that these four variables define $94 \%$ of the total variations on return on assets in the banking sector. The Durbin Watson stat is also very high 2.28, indicating that there is no auto-correlation problem in the data set. Now the second dependent variable of profitability (ROE) is discussed in the pre-Basel-II policy implementation scenario. Here, only the non-performing loans (NPLR) have a positive and statistically significant relationship with bank profitability (ROE). The coefficient is showing a negative sign, which means that NPLR has a negative impact on the bank profitability. So a $100 \%$ increase in non-performing loans will cause a $36.66 \%$ decrease in the profitability. This gives support to the results of (Hosna et al., 2009) Capital adequacy (CAR) has a positive and statistically insignificant relationship with profitability with probability value greater than $5 \%$. The coefficient of CAR in positive, which explained that with an increase in capital adequacy ratio of $100 \%$, there is a $123 \%$ increase in the bank profitability (ROE), which supports the results given by (Elsiefy, 2013; Hosna et al., 2009). Financial gap ratio (FGAPR) is also positive and insignificant, with a probability value of $7.16 \%$ which is greater than $5 \%$.the positive coefficient is showing that with an increase in the financial gap of $100 \%$ there is $112 \%$ increase in profitability in terms of return on equity (ROE). This gives support to the results determined by (Siaw, 2013) in his study. Net loans to deposit ratio also have a positive and insignificant relationship with bank profitability (ROE). But the coefficient is negative, showing that an increase in net loan to deposit ratio (NLD) will result in a $55.78 \%$ decrease in the profitability indicator ROE.

$\mathrm{R}$ squared is relatively high, with a $77.45 \%$ value, showing that $77.45 \%$ profitability can be generated by using these variables. The F-static value is 4.72 , which is insignificant and explains the results to be valid. Durbin Watson's test statics is 2.15 , which is also relatively high and showing that there is no chance of autocorrelation.

Table 5: Fixed and Random effect model (Model-2)

\begin{tabular}{|c|c|c|c|c|c|c|c|c|}
\hline \multirow[b]{2}{*}{ Var } & \multicolumn{4}{|c|}{ Dependent Variable (ROA) } & \multicolumn{4}{|c|}{ Dependent Variable (ROE) } \\
\hline & Coeff & S.E & t & Prob. & Coeff & S.E & t & Prob \\
\hline $\mathrm{C}$ & 51.26 & 13.99 & 3.66 & 0.00 & 100.54 & 238.3 & 0.42 & 0.68 \\
\hline NPLR & -0.12 & 0.09 & -1.28 & 0.22 & -3.66 & 1.26 & -2.8 & 0.01 \\
\hline CAR & 0.13 & 0.02 & 4.67 & 0.00 & 1.23 & 0.63 & 1.95 & 0.07 \\
\hline FGAPR & 0.61 & 0.14 & 4.17 & 0.00 & 1.12 & 3.01 & 0.37 & 0.71 \\
\hline NLD & -0.50 & 0.14 & -3.47 & 0.00 & -0.55 & 2.37 & -0.2 & 0.81 \\
\hline \multicolumn{5}{|c|}{$\begin{array}{l}\text { Effects Specification } \\
\text { Period fixed (dummy variables) }\end{array}$} & \multicolumn{4}{|c|}{$\begin{array}{l}\text { Effects Specification } \\
\text { Period fixed (dummy variables) }\end{array}$} \\
\hline \multicolumn{3}{|c|}{ R-squared } & \multicolumn{2}{|l|}{0.94} & \multicolumn{2}{|c|}{ R-squared } & \multicolumn{2}{|l|}{0.77} \\
\hline \multicolumn{3}{|c|}{ Adjusted R-squared } & \multicolumn{2}{|l|}{0.90} & \multicolumn{2}{|c|}{$\begin{array}{l}\text { Adjusted R- } \\
\text { squared }\end{array}$} & \multicolumn{2}{|c|}{0.61} \\
\hline \multicolumn{3}{|l|}{ F-statistic } & \multicolumn{2}{|l|}{26.76} & \multicolumn{2}{|c|}{ F-statistic } & \multicolumn{2}{|c|}{4.72} \\
\hline \multicolumn{3}{|c|}{ Durbin-Watson stat } & \multicolumn{2}{|l|}{2.28} & \multicolumn{2}{|c|}{ Durbin-Watson } & \multicolumn{2}{|c|}{2.15} \\
\hline
\end{tabular}

Results of Profitability Model for the Period 2010-2015 (Post Basel-II Implementation)

In table 6, capital adequacy ratios (CAR) significantly influence profitability (ROA) as the probability value is less than $5 \%$. The coefficient has a positive sign, which shows that a $100 \%$ increase in CAR tends to increase by $15.8 \%$ in the profitability indicator ROA. Non-performing loans have an insignificant and positive relationship with profitability. The coefficient has a negative sign which explained that an increase in NPLR is $100 \%$; there is a decrease in profitability by $5.9 \%$. These indicators support the results of (Hosna et al., 2009; Kaaya \& Pastory, 2013). Financial gap ratio (FGAPR) has an insignificant impact on profitability ROA, and it has a negative coefficient, which shows that with an increase in FGAPR, the profitability goes down.

Similarly, net loan to deposit (NLD) also has an insignificant and positive relationship with profitability with a positive coefficient showing that when the NLD ratio increases by $100 \%$, the profitability indicator ROA decreases by $42.76 \%$. These results support the researchers presented by (Elsiefy, 2013; Siaw, 2013). This model has an R-squared value of 0.89 , which is significantly very high and showing that $89 \%$ of the total profitability depends upon these independent variables. F stat value is also high at 16.07. The Durbin Watson Stat is 1.58, which is relatively high and explained that there is no autocorrelation exists in the model.

On the other hand, the ROE model showed that the capital adequacy ratio (CAR) has a positive and significant impact on profitability, which shows that the CAR has played a vital role in determining the profitability of banks. It has the positive sign of coefficient suggesting that a $100 \%$ increase in CAR tends to increase the banks' $88.33 \%$ profitability. The non-performing loans (NPLR) have insignificantly influenced the profitability (ROE), but the coefficient has a negative sign. The negative sign depicts the results as a $100 \%$ increase in the NPLR gives results in decreasing the profitability ROE by $77.58 \%$. These results support the studies of (Hosna et al., 2009; Kaaya \& Pastory, 2013; Li, F. \& Zou, 2014; Masoud et al., 2013). Financial gap ratio (FGAPR) has a positive and insignificant impact on the profitability (ROE), showing that this has no worth in the model to measure the profitability by using the FGAPR. But it has a negative sign of coefficient, which explained that $100 \%$ changes in FGAPR change the profitability by $41 \%$. Net loan to deposit (NLD) ratio has positively and significantly influenced the profitability ROE of the banks as showing in the Pakistani banking system. It has a negative coefficient and showed that with a $100 \%$ change in NLD, it had increased the profitability by $92 \%$. These two indicators depict the studies' findings (Elsiefy, 2013; Dietrich \& Wanzenried, 2011; Siaw, 2013). 
R-squared has a significant and relatively high value of $71 \%$, which explained that these variables contribute $71 \%$ of the banks' total profitability. F static value of 4.68 shows the insignificant value explained that regression is valid. The Durbin Watson stat of 1.71 shows relatively high stat and gives the results that no autocorrelation exists in the data set.

Table 6: Fixed and Random effect model (Model-3)

\begin{tabular}{|c|c|c|c|c|c|c|c|c|}
\hline \multirow[b]{2}{*}{ Var } & \multicolumn{4}{|c|}{ Dependent Variable (ROA) } & \multicolumn{4}{|c|}{ Dependent Variable (ROE) } \\
\hline & Coeff & S.E & t & Prob. & Coeff & S.E & $\mathbf{T}$ & Prob. \\
\hline $\mathrm{C}$ & -1.50 & 3.47 & -0.43 & 0.67 & -35.27 & 41.07 & -0.85 & 0.40 \\
\hline NPLR & -0.05 & 0.05 & -1.16 & 0.25 & -0.77 & 0.60 & -1.29 & 0.21 \\
\hline CAR & 0.15 & 0.02 & 5.95 & 0.00 & 0.88 & 0.31 & 2.81 & 0.01 \\
\hline FGAPR & -0.01 & 0.02 & -0.50 & 0.61 & -0.40 & 0.35 & -1.16 & 0.26 \\
\hline NLD & 0.04 & 0.034 & 1.22 & 0.23 & 0.92 & 0.41 & 2.23 & 0.03 \\
\hline \multicolumn{5}{|c|}{$\begin{array}{l}\text { Effects Specification } \\
\text { Period fixed (dummy variables) }\end{array}$} & \multicolumn{4}{|c|}{$\begin{array}{l}\text { Effects Specification } \\
\text { Period fixed (dummy variables) }\end{array}$} \\
\hline \multicolumn{3}{|c|}{ R-squared } & \multicolumn{2}{|l|}{0.89} & \multicolumn{2}{|c|}{ R-squared } & \multicolumn{2}{|l|}{0.71} \\
\hline \multicolumn{3}{|c|}{ Adjusted R-squared } & \multicolumn{2}{|l|}{0.83} & \multicolumn{2}{|c|}{$\begin{array}{l}\text { Adjusted R- } \\
\text { squared }\end{array}$} & \multicolumn{2}{|l|}{0.55} \\
\hline \multicolumn{3}{|c|}{ F-statistic } & \multicolumn{2}{|l|}{16.07} & \multicolumn{2}{|c|}{ F-statistic } & \multicolumn{2}{|l|}{4.68} \\
\hline \multicolumn{3}{|c|}{ Durbin-Watson stat } & \multicolumn{2}{|l|}{1.58} & \multicolumn{2}{|c|}{ Durbin-Watson } & \multicolumn{2}{|l|}{1.71} \\
\hline
\end{tabular}

\section{Conclusion and Recommendations}

The primary purpose of this study is to examine the impact of credit risk and liquidity risk on banks' profitability, specifically in the commercial banks of Pakistan. The analysis has been done in three phases to answer our research questions. The results obtained from the regression models show that the analysis of the model for the whole period 2006-2015, the capital adequacy ratio (CAR), has the positively and significantly influenced the profitability indicators ROA and ROE. This explained that CAR has an impact on the profitability of the banks. On the other hand, nonperforming loans (NPLR) is a significant impact on ROA but insignificantly cause the ROE in our model. The financial gap ratio (FGAPR) has an insignificant relationship with both indicators of profitability ROA and ROE.

Similarly, the net loan to deposit (NLD) ratio also has positive and insignificant relation with profitability. In this whole period model, we conclude that NPLR and CAR ratios have a significant impact on profitability. As the non-performing loans are high, the profitability tends to be decreased. At the same time, FGAPR and NLD ratios have not influenced in the model for the whole period model. While discussing the impact of credit risk and liquidity risk in pre-Basel-II implementation on the profitability for four years 2006-2009, a non-performing loan (NPLR) ratio has a positive and significant effect on the profitability indicator ROE. Insignificant relation with ROA. The coefficient has a negative sign with ROA and ROE, which shows that an increase in NPLR results from decreases in profitability.

The impact of credit risk, liquidity risk on banks' profitability in post-Basel-II implementation for six years 2010-2015. The ROA, and ROE model discussed the results that capital adequacy (CAR) ratio has positively and significantly influence the profitability of banks in both ROA and ROE. Non-performing loans (NPLR) and the financial gap (FGAPR) ratio have a positive and insignificant relationship with banks' profitability.

On the other hand, the ROE is positively and significantly influenced by the CAR, NPLR, and NLD ratios in pre-Basel-II and Post Basel-II, respectively. In contrast, the FGAPR has an insignificant relationship with ROE in the period, pre-Basel-II, and post-Basel-II implementation.
Thus, in concluding all the models, the capital adequacy (CAR) ratio has a significant influence on banks' profitability. In contrast, the NPLR, FGAPR, and NLD ratios have a reasonable but not significant impact, which can be fairly validated by relevant studies. (Akhtar et al., 2011; Elsiefy, 2013; Kaaya \& Pastory, 2013; Siaw, 2013) discuss the impact of these variables on ROA and ROE and show that CAR influences profitability while others positively and negatively impact the profitability in different scenarios. Their studies suggest that higher capital adequacy requirement contributes positively to the bank profitability, which is consistent with our findings. The $\mathrm{R} 2$ is also more than $70 \%$, which shows that these independent variables have achieved profitability.

Hence, the bank's profitability, which is calculated by either the ROA or ROE, credit risk, and liquidity risk, could be proved to be the significant determinant which could impact the bank profitability. Indicating the different statistical significance levels in different scenarios of the whole period, pre-Basel-II, and post Basel-II duration. Thus, the banks with higher exposure to credit risk and liquidity risk tend to enhance the profitability of the banking sector of Pakistan.

\section{Recommendations}

From the findings of this study, the conclusion has been derived and suggested the following recommendations; an efficient risk management system would guarantee the bank's profitability and benefits to the individuals, businesses, and the whole economy. Keeping in view the non-performing loans, as high risk tends to high profit but on the other hand, keeping in the safe side, nonperforming loans should be in control so that profitability can be enhanced and loan losses can be minimized. The diversification of NPLs should be controlled to save the chances of loss. The positive relationship of capital adequacy (CAR) ratio suggested that capital adequacy policy should be strictly followed to maximize the banks' profitability. While discussing the financial gap ratio (FGAPR), the insignificant relationship showed that the financial gap ratio does not play much role in banks' profitability. The implication of this result can be discussed as Pakistani banks that decrease their exposure to liquidity risk indicators of FGAPR by loaning less of their deposits tend to minimize profitability due to high-interest rates. So banks should revise their loaning policies to increase the percentage of deposits as well as advances to enhance their profitability.

Net loan to deposit (NLD) ratio has a significant influence on the profitability with ROA but not a significant impact with ROE. This suggested that banks need to balance and foresee the margins of return on the loans and find the elements which cause the chances of loss. It is further recommended that by adopting a sound risk management system and strong corporate governance, it will reduce the credit risk and liquidity risk and ultimately enhance the profitability of banks in Pakistan.

\section{References}

Abbas, F., Tahir, M., \& Rehman, M. U. (2012). A comparison of financial performance in the banking sector: some evidence from pakistani commercial banks. Journal of Business Administration \& Education, 1(1), 1-14.

Abdullah, A., Khan, A. Q., \& Nazir, N. (2012). A comparative 
study of credit risk management: A Case study of domestic and foreign banks in Pakistan. Academic Research International, 3(1), 371-377.

Accountants, C. (2015). Snapshot of results of banks in Pakistan, snapshot of results of banks in Pakistan six months period ended 30 June 2015, 2015.

Aduda, J., \& Gitonga, J. (2011). The relationship between credit risk management and profitability among the commercial banks in Kenya. Journal of Modern Accounting \& Auditing, 7(9), 934 946.

Afriyie, H. O. and Akotey, J.O. (2012). Credit risk management and profitability of selected rural banks in Ghana . Catholic University College of Ghana.

Ahmad, A., Malik, M. I., \& Humayoun, A. A. (2010). Banking developments in Pakistan: A journey from conventional to Islamic banking. European Journal of Social Sciences, 17(1), 12-17.

Ali, K., Akhtar, M. F., \& Ahmed, H. Z. (2011). Bank-specific and macroeconomic indicators of profitability-empirical evidence from the commercial banks of Pakistan. International Journal of Business \& Social Science, 2(6), 235-242.

Al-Tamimi, H., Al-Mazrooei, F. (2007). Banks' risk management: A comparison study of UAE national and foreign banks. The Journal of Risk \& Finance, 8(1), 394-409.

Anas, E., \& Mounira, B. A. (2008). Managing risks and liquidity in an interest free banking framework: The case of the islamic banks. International Journal of Business \& Management, 3(9) 80-95.

Anderson, C. R., \& Reeb, M. D. (2004). Board composition: Balancing family influence in S\&P 500 firms. Administrative Science Quarterly, 49(1), 209-237.

Powell, A. (2002). A capital accord for emerging economies?. The World Bank.

Aspachs, O., Nier, E., \& Tiesset, M. (2005). Liquidity, banking regulation and the macroeconomy: evidence on bank liquidity holdings from a panel of UK-resident banks, Bank of England Working Paper.

Balin, B. J. (2008). Basel I, Basel II, and emerging markets: A nontechnical analysis. Available at SSRN 1477712.

Baltagi, Badi H. 2001. Econometric Analysis of Panel Data. Wiley, John \& Sons.

Basel

http://www.bnm.gov.my/guidelines/01_banking/01_capital_ adequacy/02_basel1.pdf accessed 2009-03-14

Basel, I. I. (2006). Bank for international settlements BIS: International convergence of capital measurement and capital standards: Revised framework-comprehensive Version.

Bessis, J. (2002). Risk management in banking (2nd ed.). Chichester, UK: John Wiley and Sons.

Bonfim, D. \& Kim, M. (2012). Liquidity Risk in Herding: Is there Herding? Available at papers.ssrn.com/sol3/papers.cfm? abstract_id=2163547

Boudriga, A., Taktak, N. B. and Jellouli, S. (2009). Banking supervision and nonperforming loans: a cross-country analysis. Journal of Financial Economic Policy, 1(4), 286-318.

Brewer III E., Jackson III E. W.,(2006) A note on the "risk- adjusted" price-concentration relationship in banking. Journal of Banking \& Finance, 30, 1041-1054

Chirwa, E. W. (2003). Determinants of commercial bank's in Malawi: A cointegration approach. Applied Financial Economics, 13, 565-571.

Choudhry, M. (2011). An introduction to banking. Chichester, U.K.: John Wiley \& Sons.

Demirgüç-Kunt, A., Laeven, L., \& Levine, R. (2003). The impact of bank regulations, concentration, and institutions on bank margins, World Bank Policy Research Working Paper NO. 3030.

Diamond, D.W. \& Rajan, R.G. (2001), Liquidity risk, liquidity creation, and financial fragility: A theory of banking, The Journal of Political Economy, 109(2), 287-327.

Dinger, V. (2009). Do foreign-owned banks affect banking system liquidity risk?. Journal of Comparative Economics, 37(4), 647657.

Eken, M. H., \& Kale, S. (2013). Evaluating the efficiency of Turkish banks: A risk and profitability approach. Journal of CENTRUM Cathedra: The Business and Economics Research Journal, 6(1). http://doi.org/10.7835/jcc-berj-2013-0081

European Central Bank. (2010). Beyond Roe-How to measure bank performance. Appendix to the report on EU banking structures. $\quad$ Retrieved from http://www.ecb.europa.eu/pub/pdf/other/beyondroehowtomeas urebankperformance201009en.pdf.

Frazer, D.R.; Zhang, H. (2009) Mergers and long-term corporate performance: Evidence from cross-border bank acquisitions. Journal of Money, Credit \& Banking, 41(7), 1503-1513.

Funso, K., Kolade, A., \& Ojo, O. (2012). Credit risk and commercial banks' performance in Nigeria: A panel model approach. Australian Journal of Business \& Management Research, 2(02), 31-38.

Goddard, J., Molyneux, P. and Wilson, J. O. (2004). The profitability of european banks: A cross-sectional and dynamic panel analysis. The Manchester School, 72(3), 363-381.

Godlewski, C. (2005). Bank capital and credit risk taking in emerging market economies. Journal of Banking Regulation, 6(2), 128-145.

Gregoriou, G. N., \& Hoppe, C. (2008). The handbook of credit portfolio management. McGraw-Hill.

I Greuning, H. V., \& Bratanovic, S. B. (2009). Analyzing banking risk: A framework for assessing corporate governance and? fnancial risk (3rd ed.). Washington, DC: The World Bank.

Gujarati, D.N. (2004) Basic econometrics, Fourth Edition, MacGraw-Hill Companies.

Guru, B.K., Staunton, J., Balashanmugam, B., (1999). Determinants of commercial bank profitability in Malaysia. In: Paper presented at the Proceedings of the 12th Annual Australian Finance and Banking Conference, Sydney, Australia, December 16-17, 1999.

Halling, M. \& Hayden, E. (2006). Bank failure prediction: A twostep survival time approach",C.R.E.D.I.T. Conference, Austrian National Bank, Vienna, p. 31.

Haneef, S., Rana, M. A., \& Karim, Y. (2012). Impact of risk management on non-performing loans and profitability of 
banking sector of Pakistan. International Journal of Business \& Social Science, 3(7), 307-315.

Hasan, M. (2002, April). The Significance of Basel 1 and Basel 2 for the future of the banking industry with special emphasis on credit Information. In Central Bank of Jordan, Credit Alliance/Information Alliance Regional Meeting.

Hassan, A. (2009). Risk management practices of Islamic banks of Brunei Darussalam. The Journal of Risk Finance, 10(1), 23-37.

Hausman, J. (1978). Specification tests in econometrics. Econometrica, 46(6), 1251-1272.

Hosna, A., Manzura, B., \& Juanjuan, S. (2009). Credit risk management and profitability in commercial banks in Sweden. rapport nr.: Master Degree Project 2009: 36.

Hsiao, C. (2003). Analysis of Panel Data, Cambridge: Cambridge University Press (Econometric Society monograph No. 34).

Hsiao, C. (2005). Why Panel Data?, Singapore Economic Review, 50(2), 143- 154.

Hsiao, C. (2006). Panel Data: Advantages and Challenges, IEPR Working Paper 06.49, Institute of Economic Policy Research, University of Southern California.

Hussain, M. S., \& Ahmad, K. (2012). Challenges and failure of implementation of Basel accord II and reasons to adopt Basel III both in Islamic and Conventional Banks. International Journal of Business \& Social Research (IJBSR), 2(4), 149-174.

Hyun, J. and Rhee, B. (2011). Bank capital regulation and credit supply. Journal of Banking \& Finance, 35(2), 323-330.

Iion, T. \& Dragos, P. (2006). Policies of the commercial banks liquidity management in the crisis context, Bank of Romania Working Paper.

Ismal, R. (2010). Assessment of liquidity management in Islamic banking industry. International Journal of Islamic and Middle Eastern Finance and Management, 3(1), 147-167.

Ismal, R. (2010), "Strengthening and improving the liquidity management in Islamic banking", Humanomics, 26(1), 1835. https://doi.org/10.1108/08288661011024977

Jackson, P. (1999), Capital requirement and bank behaviour: The impact of Basel accord. Workingpaper, BIS.

Jenkinson, N. (2008). Strengthening regimes for controlling liquidity risk, Euro Money Conference on Liquidity and Funding Risk Management, Bank of England, London, p. 9.

Kaaya, I., \& Pastory, D. (2013). Credit risk and commercial banks performance in Tanzania: A panel data analysis. Research Journal of Finance \& Accounting, 4(16), 55-63.

Kauko, K. (2012). External deficits and non-performing loans in the recent financial crisis. Economics Letters, 115(2), 196-199.

Klein, N. (2013). Non-performing loans in CESEE: Determinants and impact on macroeconomic performance. IMF Working Paper.

Koch, T. W. and Macdonald, S. S. (2014). Bank management. [online] Available at: http://books.google.se/books?id=YzG32Wa3e3gC \& printsec $=$ frontcover $\&$ source $=\mathrm{gbs} \quad$ _ViewAPI\&redir_esc $=\mathrm{y} \# \mathrm{v}=$ onepage \&q\&f= false [Accessed: 27 Mar 2014].

Koch, T., \& MacDonald, S. S. (2003). Bank management (5th ed.). South Western: Thomson.

Kosmidou, K., Tanna, S., Pasiouras, F., (2005). Determinants of profitability of UK domestic banks: panel evidence from the period 1995-2002. In: Proceedings of the 37th Annual Conference of the Money Macro and Finance (MMF) Research Group, Rethymno, Greece, September 1-3, 2005.

Kwambai, K. D., Wandera, M. (2013). Effects of credit information sharing on nonperforming loans: The case of Kenya commercial banks. European Scientific Journal, 9(13), 168-193.

Lastra, B.M. (2004). Risk-based capital requirements and their impact upon the banking industry: Basel II and CAD III. Journal of Financial Regulation \& Compliance, 12(3), 225-40.

Li, F. \& Zou, Y. (2014). The impact of credit risk management on profitability of commercial banks: A study of Europe. Umeå School of Business and Economics. https://www.divaportal.org/smash/get/diva2:743402/FULLTEXT01.pdf

Lind, G. (2005). Basel II-the new framework for bank capital. Sveriges Riksbank Economic Review, 2(2005), 22-38.

Molyneux, P. (Ed.). (2011). Bank performance, risk and firm financing. Springer.

Majnoni, G. and Powell, A. (2005). Reforming bank capital requirements: Implications of Basel II for Latin American countries, Economi'a, 5(2), 105-49.

Malik, L. F. (2008). Basel II Implementation in Pakistan SBP Approach to Risk Management.

Masoud, B., Iman, D., Zahra, B., \& Samira, Z. (2013). A study of risk management in Iranian banks. A study of risk management in Iranian banks. Research Journal of Recent Sciences, 2(7), 17.

Maury, B. (2006). Family ownership and firm performance: Empirical evidence from Western European corporations. Journal of Corporate Finance, 12, 321-341.

Mishkin, F.S., \& Eakins, S.G.(2009). Financial markets and institutions. Pearson Education, Boston.

Nimalathasan, B. (2008). A comparative study of financial performance of banking sector in Bangladesh. An application of CAMELS rating system. Universitatii Bucuresti. Analele. Seria Stiinte Economice si Administrative, 2(2008), 141-152.

Ojo, M. (2010). Risk management by the Basel committee: Evaluating progress made from the 1988 Basel accord to recent developments. Journal of Financial Regulation \& Compliance, $18,305-315$.

Ongore, V. O. and Kusa, G. B. (2013). Determinants of financial performance of commercial banks in Kenya. International Journal of Economics \& Financial Issues (IJEFI), 3(1), 237252.

SBP. (2005). Roadmap for the implementation of basel II in Pakistan. http://www.sbp.org.pk/bsd/2005/C3.htm

Park, J. (2012). Corruption, soundness of the banking sector, and economic growth: A cross-country study. Journal of International Money \& Finance, 31(5), 907-929.

Plasmans, J. (2006). Modern linear and nonlinear econometrics. New York: Springer Verlag.

Protiviti Inc. (2013). The bulletin: Ten keys to managing reputation risk. Available through: http://www.protiviti.com/enUS/Documents/Newsletters/Bulletin/The-Bullet in-Vol-5Issue-2-10-Keys-Managing-Reputation-Risk-Protiviti.pdf 
[Accessed: 9 Mar 2014].

Rahman, M. M., Jongwanich, J., Venkatesh, S., \& Siengthai, S. (2012). Banking Sector reforms in Bangladesh and its impact. (Master Dissertation) Asian Institute of Technology. School of Management.

Reserve Bank of New Zeland. (2007) Capital adequacy ratios for banks -simplified explanation and example of calculation. [online] Available

http://people.stern.nyu.edu/igiddy/articles/ capital_adequacy_calculation.pdf [Accessed: 9 Mar 2014].

Ben Selma, M. R., Abdelghani, E. C. H. C. H. A. B. I., \& Rajhi, M. T. (2013). Risk management tools practiced in Tunisian commercial banks. Studies in Business \& Economics, 8(1), 5578.

Rime, B. (2001). Capital requirements and bank behaviour: Empirical evidence for Switzerland. Journal of Banking \& Finance, 25(4), 789-805.

Risk (2002a). Swiss and UK banks set to win as Japanese lose in Basel II, Vol.15 (1).

Rixtel, V. A., Alexopoulou, I., Harada, K., (2003). The new Basel accord and its impact on Japanese banking: A qualitative analysis. Centre for Economic Institution Working Paper Series, Institute of Economic Research, number 2003-25.

Roger, W. Ferguson Jr. (2003). Capital standards for banks: The evolving basel accord. Federal Reserve Bulletin, 89(9), 395405.

Rowe, D., Jovic, D. and Reeves, R. (2004). Bank capital management in the light of Basel II. Journal of Performance Management, 17(1), 15-25.

Ruziqa, A. (2013). The impact of credit and liquidity risk on bank financial performance: The case of Indonesian conventional bank with total asset above 10 trillion Rupiah. International Journal of Economic Policy in Emerging Economies, 6(2), 93106.

Salas, V. and Saurina, J. (2002). Credit risk in two institutional regimes: Spanish commercial and savings banks. Journal of Financial Services Research, 22(3), 203-224.

Santomero, A. M. (1997). Commercial bank risk management: An analysis of process. The Wharton School of the University of Pennsylvania, Philadelphia, PA.

Saunders, A. and Cornett, M. M. (2014). Financial institutions management: A risk management approach. [e-book] New York: McGraw-Hill Higher Education.

Saunders, A., \& Cornett, M. M. (2006). Financial institutions management: A risk management approach. McGraw-Hill, Boston.

Sawada, M. (2010). Liquidity risk and bank portfolio management in a financial system without deposit insurance: Empirical evidence from prewar Japan. International Review of Economics \& Finance, 19(3), 392-406.

Shafiq, A., \& Nasr, M. (2010). Risk management practices followed by the commercial banks in Pakistan. International Review of Business Research Papers, 6(2), 308-325.

Shen, C.H.; Chen, Y.K., Kao, L.F. and Yeh C.Y. (2009). Bank liquidity risk and performance. http://www.finance.nsysu.edu.tw/
SFM/17thSFM/program/FullPaper/083-231345511.pdf

Siaw, S. (2013). Liquidity risk and bank profitability in Ghana (Doctoral dissertation, University of Ghana).

Sinkey, J. (2002). Commercial bank financial management: In the financial-services industry. 6th Edition Prentice Hall, Upper Saddle River, NJ.

Stevens, B. (2008). Corporate ethical codes: Effective instruments for influencing behavior. Journal of Business Ethics, 78, 601609.

Sufian, F. (2009). Determinants of bank efficiency during unstable macroeconomic environment: Empirical evidence from Malaysia. Research in International Business \& Finance, 23, 54-77.

Sufian, F., Chong, R.R. (2008), Determinants of Bank Profitability in a Developing Economy: Empirical Evidence from the Philippines. Asian Academy of Management Journal of Accounting \& Finance, 4(2), 91-112.

Tafri, F. H., Hamid, Z., Meera, A. K. M., \& Omar, M. A. (2009). The impact of financial risks on profitability of Malaysian commercial banks: 1996-2005. International Journal of Social, Human Science and Engineering, 3(6), 268-282.

The Joint Forum (2006, May). The management of liquidity risk in financial groups. Technical report, The Joint Forum: Basel Committee on Banking Supervision, International Organisation of Securities Commissions, International Association of Insurance Supervisors, Basel, Switzerland. Available at http://www.bis.org/publ/joint16.pdf [Accessed: 27 Mar 2014].

Uddin, H. (2009). Reexamination of stock liquidity risk with a relative measure. Studies in Economics \& Finance, 26(1), 2435.

Vaihekoski, M. (2009). Pricing of liquidity risk: Empirical evidence from Finland. Applied Financial Economics, 19(19), 1547-1557.

Van Gestel, T., \& Baesens, B. (2008). Credit Risk Management: Basic concepts: Financial risk components, Rating analysis, models, economic and regulatory capital. OUP Oxford.

Vodova, P. (2011). Liquidity of Czech commercial banks and its determinants. International Journal of Mathematical Models \& Methods in Applied Sciences, 5(6), 1060-1067.

Grier, W. A. (2007). Credit analysis of financial institutions. Euromoney Books.

Yang, C. (2012). Service, investment, and risk management performance in commercial banks. The Service Industries Journal, 32(12), 2005-2025.

Zaidi, S. M. S. (2006). Basel II - An overview, members' information \& education series. The Institute of Chartered Accountants of Pakistan.

Zheng, H., \& Shen, Y. (2008). Jump liquidity risk and its impact on CVaR. The Journal of Risk Finance, 9(5), 477-492. 